\title{
Do political changes aimed at reducing Amazonian deforestation contribute to ecological intensification?
}

\author{
Nathalie Cialdella ${ }^{1,6}$ \\ Soraya Carvalho ${ }^{2}$ \\ Vania Vaz ${ }^{3}$ \\ Tienne Barbosa ${ }^{4}$ \\ Marcelo Thâles ${ }^{5}$ \\ Moises Mourão 6 \\ René Poccard-Chapuis ${ }^{6,7}$ \\ Jean-François Tourrand ${ }^{8}$ \\ ${ }^{1}$ CIRAD \\ UMR Innovation \\ 34398 Montpellier \\ France \\ $<$ nathalie.cialdella@cirad.fr $>$ \\ 2 UFPA- NCADR \\ Universidade Federal do Pará - UFPA \\ Núcleo de Ciências Agrárias e \\ Desenvolvimento Rural \\ Rua Augusto Corrêa, $\mathrm{N}^{\circ} 01$ \\ Campus Universitário do Guamá \\ 66075-110 Belém \\ Pará \\ Brasil \\ <soraya@ufpa.br> \\ ${ }^{3}$ UNB - CDS \\ UNB - Centro de desenvolvimento \\ sustentavel \\ Campus Darcy Ribeiro \\ Asa Norte \\ Brasília - DF, 70910-900 \\ Brasil \\ <vaniavaz22@hotmail.com> \\ ${ }^{4}$ Agroparistech \\ 16 , rue Claude Bernard \\ 75005 Paris \\ France \\ <tiennejo@yahoo.com.br> \\ ${ }^{5}$ Museo Goeldi \\ 62 Av. Gov. Magalhães Barata \\ 328 - São Brás \\ PA, 66060-281 \\ Brasil \\ $<$ mcthales@museu-goeldi.br> \\ ${ }^{6}$ Embrapa \\ Embrapa Amazônia Oriental. Trav. \\ Dr. Enéas Pinheiro, $\mathrm{s} / \mathrm{n}^{\circ}$ \\ Caixa postal 48, CEP 66095-100 \\ Belém, PA \\ Brasil
}

\footnotetext{
Reprints: N. Cialdella

doi: 10.1684/agr.2015.0761
}

\begin{abstract}
Extensive livestock farming was the driver of agricultural colonization and territorial structuring in the Amazon. Since 2008, Amazonian agriculture has been faced with radical changes in Brazilian policies concerning agricultural land use and the preservation of forest areas. The very viability of livestock systems is threatened and there is thus an urgent need for feasible alternatives to enable the development of sustainable agriculture. Some alternatives are currently being tested by public extension services and private operators. The question is, can these alternatives really be considered as ecological intensification? Defined as ecologically friendly agricultural development, this new trend of intensification aims to reconcile cattle ranching and the protection of Amazon forest ecosystems. Our analysis, based on three contrasted municipalities in Pará State, focuses on the points of view of different stakeholders in the livestock sector. Results show the dominance of classical intensification among the alternatives envisaged, but it is an option that small family farmers cannot easily afford. Alternatives based on land sharing, which promotes agricultural production and environmental preservation on the same areas, are less well known and will require more coordination among local actors.
\end{abstract}

Key words: Brazil; Amazonia; ecological intensification; livestock raising; family farming; public policy.

Subjects: economy and rural development; forestry; territory, land use, agricultural and food production policy.

\section{Résumé}

L'évolution des politiques publiques pour réduire la déforestation en Amazonie contribue-t-elle à l'intensification écologique ?

L'élevage extensif a été un moteur dans l'avancée des fronts agricoles et la construction des territoires en Amazonie brésilienne. Depuis 2008, l'agriculture amazonienne est confrontée à des changements radicaux de la politique brésilienne concernant l'usage des terres agricoles et la préservation des zones forestières. La viabilité des systèmes d'élevage est aujourd'hui menacée ; il est urgent de trouver et de mettre en œuvre des solutions viables, techniques et sociales, pour permettre le développement durable de l'agriculture en Amazonie. Une série d'alternatives sont testées par les services publics, privés et des organisations non gouvernementales (brésiliennes et internationales) afin d'amorcer une trajectoire d'intensification tout en préservant la forêt. Notre question est : les alternatives envisagées contribuent-elles à un mouvement d'intensification écologique? Défini comme développement agricole respectueux de l'environnement, ce mouvement est considéré comme un des facteurs d'une coexistence entre élevage et forêt. Sur la base d'une étude réalisée dans trois communes contrastées de l'État du Pará, l'analyse porte sur la connaissance qu'ont les acteurs impliqués dans le secteur de l'élevage sur ces alternatives. Nous analysons également en quoi les alternatives citées par les acteurs sont liées à l'intensification écologique. Les résultats montrent qu'il s'agit la plupart

To cite this article: Cialdella N, Carvalho S, Vaz V, Barbosa T, Thâles M, Mourão M, Poccard-Chapuis $\mathrm{R}$, Tourrand JF, 2015. Do political changes aimed at reducing Amazonian deforestation contribute to ecological intensification? Cah Agric 24: 246-54. doi : 10.1684/agr.2015.0761 
<moises.mourao@embrapa.br>

$<$ rene.poccard-chapuis@cirad.fr>

7 CIRAD

UMR Selmet

34398 Montpellier

France

8 Cirad - UR Green

Avenue Agropolis,

34398 Montpellier Cedex 5

France

$<$ jean-francois.tourrand@cirad.fr> du temps de méthodes conventionnelles d'intensification, difficiles à atteindre pour les petits producteurs familiaux, et qui séparent les zones de production intensive des zones à protéger. Les alternatives basées sur l'intégration de la production agricole et de la protection de l'environnement sur les mêmes espaces sont moins connues et demandent une coordination plus grande entre les acteurs locaux.

Mots clés : Brésil ; Amazonie ; intensification écologique ; élevage ; agriculture familiale ; politique publique.

Thèmes : économie et développement rural ; forêts ; territoire, foncier, politique agricole et alimentaire.
$\mathrm{D}$ evelopment in the Brazilian Amazon is emblematic of the need to find a compromise between reaching food production goals and nature conservation worldwide. Population projections for the coming decades show that we will have to produce more food - and share it better - while reducing negative impacts on the environment and ensuring the provision of environmental services (Hubert et al., 2010). The main challenge is thus twofold: intensification and increased sustainability. The scientific community calls this trend "ecological intensification", but this concept varies widely depending on the authors and countries (Doré et al., 2011). The Amazon is a biodiversity "hot spot" and its conservation is considered to be crucial for carbon storage and climate regulation (Sheil and Murdiyarso, 2009; Soares-Filho et al., 2010). But at the same time, Brazil is the world's largest exporter of beef and nearly one third of the Brazilian herd, around 70 million cattle, is located in the Amazon (IBGE, 2010). Mining, timber exploration and cattle ranching have been the three drivers of colonization of the Brazilian Amazon (Sayago et al., 2004). As cattle ranching relies on pasture management, which is based on slash and burn practices, it is also one of the main drivers of deforestation (Poccard-Chapuis et al., 2005). In addition, livestock plays a key role in the viability of Amazonian family farms (Tourrand et al., 2002; Carvalho, 2011).

Since 2008, the federal government has tried to stop deforestation by implementing a command and control policy. All the stakeholders of the livestock sector, including cattle ranching and the beef supply chain, recognize the need to find alternatives to slash and burn. The intensification of livestock farming is widely argued to be the best alternative. Twenty years ago, supported by research conducted on a number of fazendas (large scale ranches), a necessary technological advance took place (Veiga et al., 2004) focused on integrated croplivestock systems. However, slowing down deforestation is only one aspect of conserving Amazonian ecosystems (Nepstad et al., 2014) and possible ways of intensifying livestock production have been the subject of few studies to date. This paper focuses on individual and collective technical and organizational alternatives aimed at ecological intensification or that at least do not require deforestation. It discusses conditions and ways to achieve ecological intensification (Griffon, 2013).

In the following section, we review the scientific opinions around the concept of ecological intensification and present our interdisciplinary methodology and our case study. Next, we describe the diverse alternatives mentioned by the actors as methods enabling production without deforestation. We analyze how these alternatives will inevitably lead to adjustments and deep reconfigurations of current livestock production systems, both technically and organizationally. We also examine how these alternatives are - and are not specific to family farming. In the last section, we discuss these alternatives from both social and technical points of view while keeping ecological intensification and family farming issues in mind.

\section{What does ecological intensification mean for the Amazon?}

\section{Theoretical framework for ecological intensification}

Reducing greenhouse gas emissions in the context of climate change requires the design and promotion of alternative practices, especially in agriculture. Ecological intensification is seen as a desirable way to transform agriculture. The term "ecological intensification" emerged in public and scientific debates following the failure of the green revolution with respect to ecological and social concerns (Bonny, 2011). The term "ecological intensification" covers a range of agronomical approaches, from increasing crop productivity with limited negative short-term environmental impacts, to increasing the use of ecological processes for agricultural production (Doré et al., 2011). Nevertheless, the whole range of approaches refers to only two paradigms: "weak ecological modernization", which does not require a radical shift in the most widespread agricultural practices (conventional practices) and "strong ecological modernization" which requires considering agriculture not only as a food provider, but also as an ecosystem services provider (Duru et al., 2014). Consequently, a wide range of practices and 
agricultural models can claim to be part of ecological intensification. They differ "in the way they consider the impact of the surrounding natural environment on agriculture, the impact of agriculture on the surrounding natural environment, and the way natural elements are embedded in agricultural systems" (Tittonnel, 2014). Agro-ecology may be the agricultural model that is the most embedded in nature, as it includes human beings (Altieri, 2002). In Brazil, where rural territories have been based on a strong duality and where conflicts between large and small scale farmers are common, agro-ecology has been a model that supports the autonomy of small family farmers (Wezel et al., 2009). Thus, in theory, land sharing corresponds better to a model of sustainable family farming whereas land sparing corresponds better to large scale entrepreneurial farms, fazendas (Grau et al., 2013). Faced with these different definitions, we chose to not restrict ourselves to one or the other, but rather to base our study on existing alternatives.

First, we checked local actors' perceptions of the need to shift from a dominant model of ranching, and mining of timber wood, to an intensive model that preserves the forest ecosystem. Second, we analyzed to what extent known and implemented alternatives are linked to ecological intensification and how they apply to family farms versus fazendas.

\section{Study site}

Altamira, Redenção and Paragominas are three contrasted municipalities on the agricultural frontier of the State of Pará (figure 1).

The rate of deforestation and the number of cattle are not the same in the three municipalities.

The low deforestation rate in Altamira (4\%) is in fact due to the huge size of the municipality $\left(640,679 \mathrm{~km}^{2}\right)$ and the very limited road access to the southern part. In the neighbouring municipalities, which are far smaller and almost completely settled by migrant farmers, deforestation does not exceed $40 \%$ of the land. The herd comprises half a million cattle.

In Redenção and neighbouring municipalities, the deforestation rate is far above the 20\% limit laid down in the Forest law and the 50\% limit actually tolerated. Except in Cumaru municipality where deforestation is only $41 \%$, the deforestation rate in our examples
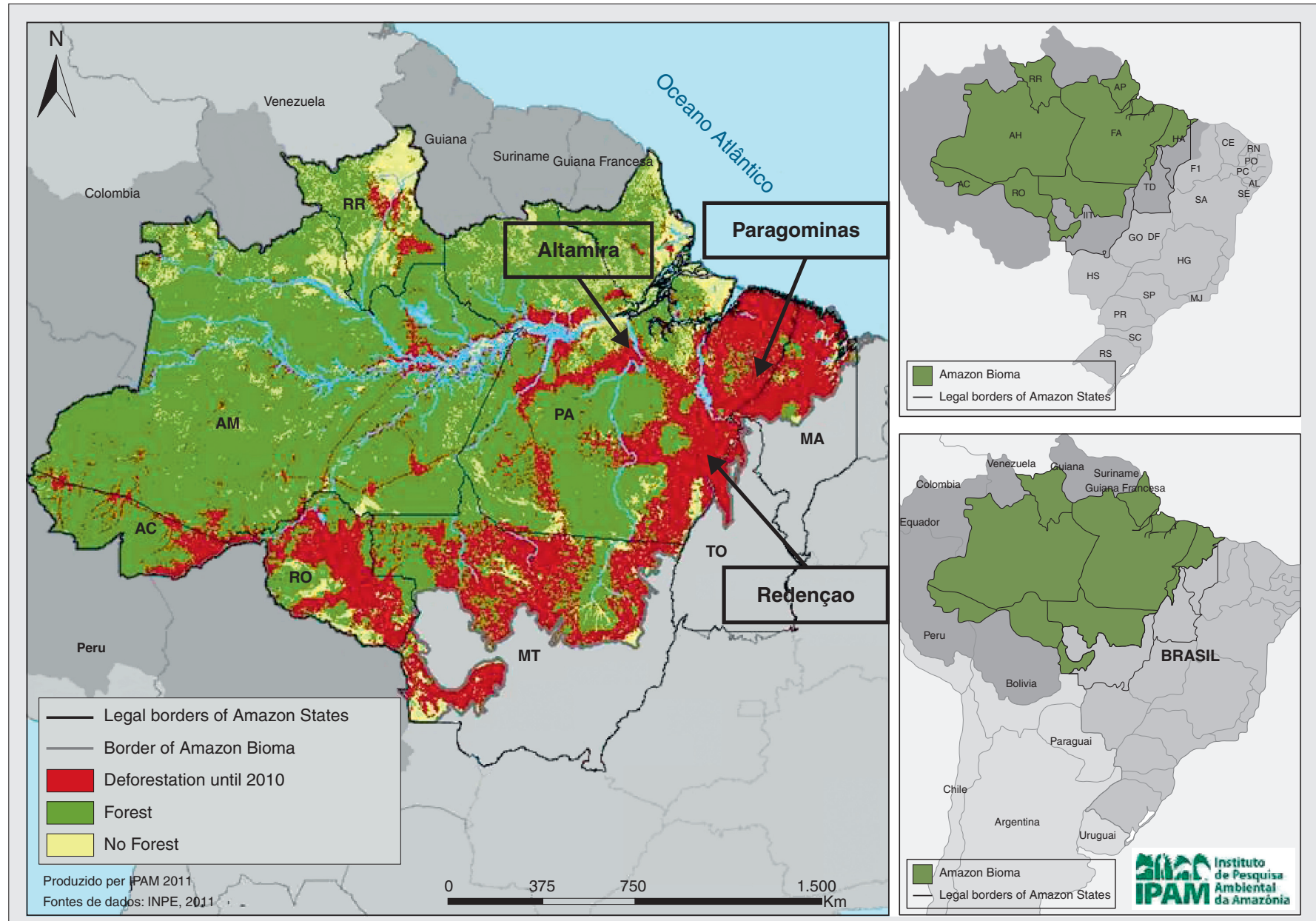

Figure 1. Deforestation in the Brazilian Amazon in 2010 (source IPAM, 2011).

Figure 1. Déforestation en Amazonie brésilienne en 2010 (source IPAM, 2011). 
is between $60 \%$ and $80 \%$. Cattle density in the deforested area is low (between $0.77 /$ ha and $0.91 /$ ha, table 1), less than the Amazonian average of one animal per hectare.

In Paragominas, deforestation is high (between 44\% and 65\%, table 1), but generally does not exceed the $50 \%$ tolerated in the state of Pará. The current low livestock density points to diversification in land use (crops and forestry).

\section{A comprehensive approach to local dynamics}

The research we conducted was interdisciplinary, and included agronomists, livestock scientists, geographers, and historians. We interviewed different groups of stakeholders involved in livestock farming:

- medium and large scale farmers;

- small family farmers (who farm less than 220 ha in Paragominas, 300 ha in Altamira and Redenção);

- livestock supply chains and agroindustry staff (traders, slaughterhouse owners, etc.);

- producers associations, cooperatives, trades unions;

- federal government and local administration staff (including extension services);
- staff of banks and financial agencies; - NGOs.

The redundancy and triangulation technique (Copans, 1999) was used to select the total number of interviews (between 12 and 15 per locality).

Open interviews were conducted to collect information to answer five questions formulated by the group of researchers:

- What were the different steps in the interactions between livestock farming and the territorial structuring? - What functions does livestock farming fulfil in local development?

- What new technologies or changes in currently used livestock systems correspond to the intensification of production?

- What factors facilitate or hinder the intensification of livestock production?

- Are there any scenarios for the future development of livestock farming in the territory?

Forty-one interviews were conducted between June and September 2011. The data were compiled by all the team members at the end of each interview and after the final interview sessions. The data were then analyzed collectively by the team during workshops before the results were published.
The efficiency of

public deforestation policies with respect to the intensification of livestock farming

In a previous paper (Vaz et al., 2012), we showed that cattle ranching was one of the main driving forces behind the colonization of the Amazon from the 1960s on, as well as behind local development. We also showed that farmers and stakeholders involved in beef supply chains have borne the brunt of the drastic change in federal policy with the launching of the consortium to stop deforestation. Despite being a federal objective, which also included the creation of trans-Amazonian highways and the capital city Brasilia in 1960, agricultural colonization was poorly planned. Until recently, land was not a limiting factor for extensive livestock production (0.8 cattle unit/ha); it was based on the slash and burn of forest plots that were replaced by managed pasture. The lack of federal and local efforts to enforce the policy encouraged deforestation beyond the legal limit. What is more, until

Table 1. Deforestation and livestock in the three study areas and seven neighbouring municipalities.

Tableau 1. Couvert forestier et cheptel dans les trois communes de l'étude et sept communes voisines.

\begin{tabular}{lccccc}
\hline Municipality & Total area (km2) & $\begin{array}{c}\text { Deforested } \\
\text { area (\%) }\end{array}$ & $\begin{array}{c}\text { Deforestation } \\
\text { per year (\%) }\end{array}$ & Total $\mathbf{n}^{\circ}$ of cattle & $\begin{array}{c}\text { Cattle density } \\
\text { (n)/ha deforested) }\end{array}$ \\
\hline Paragominas & $\mathbf{1 9 , 4 5 2}$ & $\mathbf{4 4 . 2}$ & $\mathbf{0 . 3 5}$ & $\mathbf{3 1 5 , 7 2 0}$ & $\mathbf{0 . 3 7}$ \\
\hline Rondon do Pará & 8,286 & 65.4 & 0.64 & 349,871 & 0.65 \\
\hline Tome Açu & 5,168 & 56.9 & 0.71 & 116,021 & 0.39 \\
\hline Redenção & $\mathbf{3 , 8 3 0}$ & $\mathbf{6 9 . 4}$ & $\mathbf{1 . 1}$ & $\mathbf{2 0 4 , 2 9 6}$ & $\mathbf{0 . 7 7}$ \\
\hline Santana de Araguaí & 11,607 & 60.9 & 0.35 & 545,523 & 0.77 \\
\hline Cumaru do Norte & 17,106 & 41.12 & 0.25 & 638,983 & 0.91 \\
\hline Rio Maria & 4,123 & 81.66 & 0.1 & 299,016 & 0.89 \\
\hline Altamira & $\mathbf{1 5 9 , 7 0 1}$ & $\mathbf{4 . 2 7}$ & $\mathbf{0 . 1 2}$ & $\mathbf{5 5 5 , 3 2 4}$ & $\mathbf{0 . 8 1}$ \\
\hline Brasil Novo & 6,370 & 39.73 & 0.79 & 206,099 & 0.81 \\
\hline Medicilândia & 8,271 & 23.5 & 0.57 & 103,939 & 0.53
\end{tabular}

Source : PRODES, 2010 
2008, 50\% of the area of a farm entirely covered by forest - had to be cleared to legitimize appropriation. The remaining 50\%, called the legal reserve, had to be conserved as primary forest and not exploited.

In 2008, the federal government created an environmental land register (Brazilian acronym CAR) to regularize the situation or at least to record current land use. Without this certification, livestock farmers could no longer sell animals to slaughterhouses or contract bank loans. In parallel, a consortium of federal agencies implemented a repressive command and control policy. A "blacklist" of the municipalities with the highest rates of deforestation is published annually; the process of creating protected areas is accelerating and regularizing agricultural land is now the only way to obtain environmental certification. Application of the labor law was strengthened. Livestock farmers, big and small, felt they were trapped in a deadlock. From 2008 on, all the stakeholders started looking for alternative ways to produce and market their production, at the farm, supply chain, and local scale.

\section{Alternative ways to}

\section{intensify livestock}

\section{farming: from genetics}

\section{to agro-ecology}

In all three municipalities, all the stakeholders agreed that livestock farming can no longer rely on opening up new spaces; the message "zero deforestation" has now got through to everyone, although all the stakeholders mentioned the lack of research, training, and technical and institutional support (table 2).

We classified the alternatives in three categories, depending on how they affect ecological processes and on their scale of implementation (figure 2).

\section{Conventional alternative ways of increasing livestock productivity}

Conventional alternatives deal with the production system at the scale of the individual plot or animal.
Genetics: in the Amazon, the productivity of livestock systems is still often very low. Genetic improvement is an animal scale alternative whose aim is to increase carcass weight or milk yield with dedicated breeds. This alternative can be classified as weak intensification; reducing deforestation at local scale is feasible if the other livestock practices, such as pasture management, are intensified (see below).

Pasture fertilization and plowing: renewal of pasture including soil preparation and sowing of grass, mostly Brachiaria bryzantha, even though this particular cultivar faces serious recurrent problems caused by pests. This alternative is based on the use of chemical inputs and of mechanized equipment to increase biomass production and control weed. It is widely promoted by research and extension, as well as being encouraged by agro-industry. The success of this alternative relies on the experience of individual farmers, and consequently does not require coordination (figure 2). This may be one reason for its rapid and widespread adoption. One exception is plowing on small family farms. Mechanization depends on federal or municipal development programs, which allocate collective equipment to a given rural community, and consequently requires coordination between the farmers concerned.

\section{Alternative ways of increasing overall farm viability and efficiency}

These alternatives are applied at the scale of one farm or of a group of farms, and affect the organizational level of farming. They involve different forms of diversification, from including intercrops such as animal forage in the livestock system, to relatively disconnected activities, (for example wood and livestock production), and varying rates of forest ecosystem or natural resources use. iLPF (crop-livestock-tree forest systems): a national Brazilian research program supports this alternative (Santos et al., 2010, Balbino et al., 2011) and large scale farmers consider it to be a model of modern agriculture. Crops, mainly soybean or maize, are harvested for grain or silage and may be part of the intensification of the cattle feed system. Indeed, maize silage improves the quality and quantity of both milk and meat especially in the dry season. iLPF also enables pasture renewal including using annual crops, and the planting or conservation of trees of economic value (eucalyptus or theca for timber) provide some shade for the cattle. The aim here is to increase land productivity (fertility, cash crops) and animal productivity (feeding system). It is supported by the structuring of the cereal, timber, and of course, milk and meat sectors. The diffusion of this alternative also depends on coordination between stakeholders at local scale (figure 2).

Balde cheio (Full bucket) is a Brazilian support program for the intensification of dairy farms, mainly based on increasing the productivity of animals and pasture and improving the animal feeding system (Camargo et al., 2006). In theory, this alternative is designed for small family farms and involves technical and organizational changes (figure 2). The two most frequently mentioned focuses of the balde cheio project were the rules of hygiene for milking and daily rotational grazing to improve pasture productivity using chemical fertilizers and mechanized weed control. Reconstruction of forest protected area is also an objective. Implementation generally includes an annual technical and economic diagnosis of small family farms. The prototype was implemented on ten hectares, but it is widely cited by the owners of large scale farms (fazendas) (table 2).

Agro-forestry systems (AFS): This alternative covers a range of economic farming activities that take advantage of tree species including cacao, theca, or pepper, combined with animal and vegetable production. These systems were most often mentioned by small producers and extension agents (table 2). AFS are designed to increase farm income and to take advantage of the forest ecosystem. According to current negotiations concerning the Brazilian Forest Law, the species used (cacao, pepper) could be among the species authorized for the rehabilitation degraded or protected forest areas. This alternative was mentioned by municipal secretaries and by the farmers themselves as being suitable 
Table 2. Alternatives mentioned by stakeholders, target farmers and staff of institutions.

Tableau 2. Alternatives citées par les acteurs, agriculteurs-cibles et institutions impliquées.

\begin{tabular}{|c|c|c|c|c|}
\hline Alternatives & Scale & Type of stakeholder & Target farmers & Design and Implementation \\
\hline Genetics & Plot & $\begin{array}{l}\text { Small family farmers (ATM, RDC) } \\
\text { Big farmers (PGM) } \\
\text { Rural extension (RDC, PGM) } \\
\text { Agroindustry (beef: ATM, Milk: } \\
\text { PGM) }\end{array}$ & All farmers & $\begin{array}{l}\text { Private and public } \\
\text { research and extension }\end{array}$ \\
\hline Pasture fertilization & Plot & $\begin{array}{l}\text { Small family farmers (ATM, RDC) } \\
\text { Small family farmers union (ATM) } \\
\text { Big farmers (ATM, PGM) } \\
\text { Rural extension (ATM, PGM) } \\
\text { Agroindustry (beef: ATM, RDC; } \\
\text { milk: PGM) } \\
\text { Municipal secretaries (ATM) } \\
\text { Bank (RDC, PGM) }\end{array}$ & All farmers & $\begin{array}{l}\text { Private and public } \\
\text { research and extension }\end{array}$ \\
\hline Plowing & $\begin{array}{l}\text { Plot/ } \\
\text { Territory }\end{array}$ & $\begin{array}{l}\text { Small family farmers union (ATM) } \\
\text { Big famers (ATM, RDC) } \\
\text { Big farmers union (ATM) } \\
\text { Rural extension (ATM, RDC) } \\
\text { Agroindustry (ATM) } \\
\text { Municipal secretaries (ATM) }\end{array}$ & All farmers & $\begin{array}{l}\text { Private and public } \\
\text { research and extension }\end{array}$ \\
\hline
\end{tabular}

Crop-Livestock-Forestry
Integration (iLPF)

Crop-Livestock-Forestry Farm
Integration (iLPF)

$\longrightarrow$

Balde cheio Farm

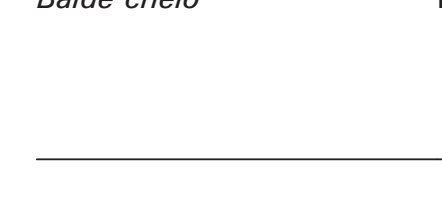

Agroforestry Systems Farm

Green municipality Territory

\begin{tabular}{lllll}
\hline Certification & Territory & $\begin{array}{l}\text { Big farmers (RDC, PGM) } \\
\text { Agroindustry (RDC) } \\
\text { Big Farmers union (RDC) }\end{array}$ & All farmers & Agroindustry + (research) \\
\hline Agro-ecology & $\begin{array}{l}\text { Farm/ } \\
\text { Territory }\end{array}$ & $\begin{array}{l}\text { Rural extension (ATM) } \\
\text { Municipal secretaries (ATM, PGM) }\end{array}$ & Small farmers NGOs + (research) \\
\hline
\end{tabular}

Small family farmers (ATM, PGM)

Small family farmers union (RDC)

Big farmers (ATM, PGM)
Rural extension (ATM, RDC)

Agroindustry (beef:

ATM, milk : RDC)

Municipal secretaries (PGM)

Bank (ATM)

NGO (environmental: PGM)
Big farmers Private and public research and extension
Small family farmers (ATM, RDC)

Small family farmers union (RDC)

Big farmers (ATM)

Municipal secretaries (ATM, RDC)

Bank (ATM)
Small family

farmers
Private and public research and extension

Big farmers (RDC, PGM)

Agroindustry (RDC)

Municipal secretaries (ATM, PGM)

All farmers

Municipality + NGOs

Small (mid)

farmers

Research + NGOs
Big Farmers (ATM, RDC, PGM)

Big farmers union (RDC)

Rural extension (ATM, RDC, PGM)

Municipal secretaries (PGM)

NGO (environmental: PGM)

ATM $=$ Altamira; RDC $=$ Redenção; PGM $=$ Paragominas 


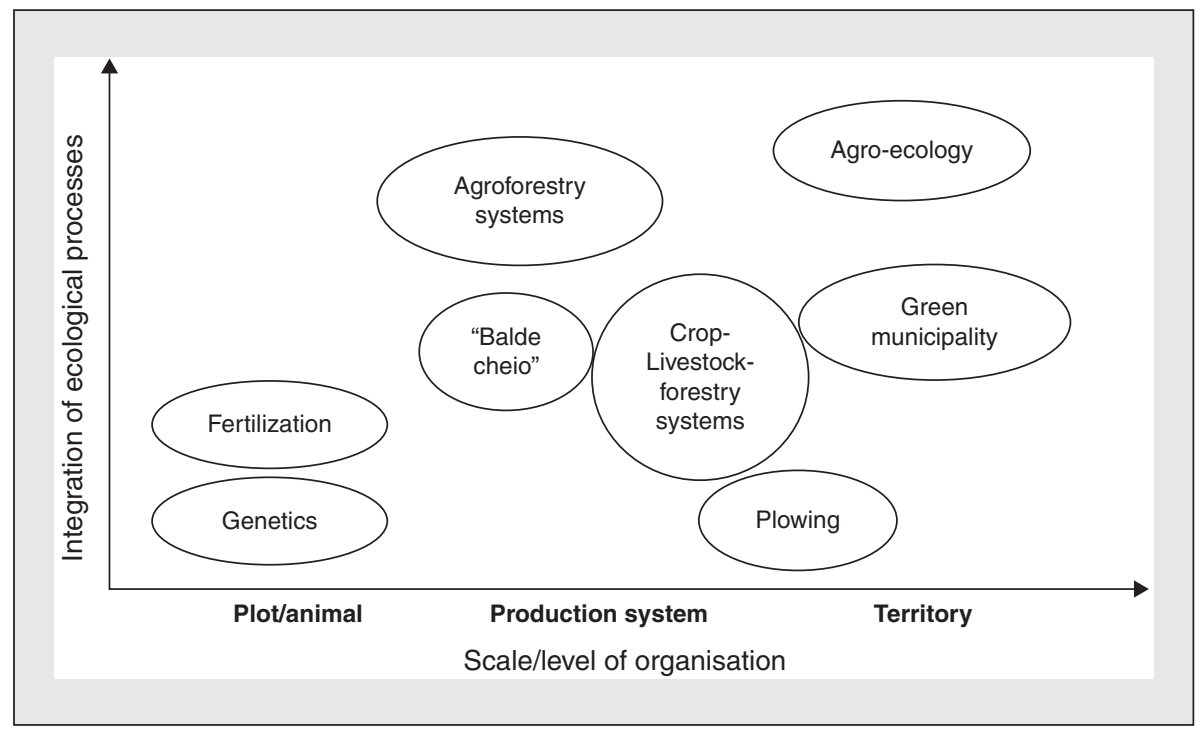

Figure 2. Alternatives to extensive livestock practices mentioned by stakeholders.

Figure 2. Alternatives aux pratiques extensives d'élevage citées par les acteurs.

for small family farms, as oppose to iLPF (table 2). One difference is the spatial organization of the species: iLPF separates crops and tree production, whereas in agroforestry systems, the tree species are mixed with crops in the same area or plot at a given time. The diffusion of this alternative is independent of the supply chain; the main goal is to reduce production costs by benefitting from ecological processes.

\section{Alternatives ways to increase the efficiency of the supply chain or of the territory}

Certification is a quality initiative that was introduced by industry (e.g. by slaughterhouses in Redenção, Paragominas and Altamira) to give a "green" image to their products. Stakeholders are taking advantage of the environmental pressures and debate to improve the efficiency of the sector. Certification defines a number of key actions that vary depending on the supply chain's specifications, and are a combination of the alternatives listed above. For example, in the case of livestock, this implies:

- compliance with environmental certification on the use of the farm land (CAR);
- increasing carcass weight; - improving feed for fattening by providing fodder in dry periods and improving pasture management.

The term green municipality refers to a local arrangement for agricultural transition, an initiative tested in Paragominas, which became a model for green development in the Amazonian state of Pará (figure 2). It consists of coordinating the actions of local institutions, including those of municipal secretaries for agriculture, for the environment and for trade, of farmers' unions, and of TNC (Nature Conservation NGO). This international NGO has been contracted to implement the rural environmental certification (CAR) of farms of over 300 ha, thus excluding family farms (table 2).

From a technical point of view, the initiative consists of implementing iLPFs by combining actions at three scales, the plot or animal scale, the farm scale, and the municipal scale. The introduction of iLPFs depends on the soil potential for crop production, which necessarily relegates livestock production systems to areas of low agronomic potential. iLPFs are located near roads to facilitate the transport and storage of grain.

Agro-ecology aims to increase the autonomy of small family farms based on organic agriculture. Currently, agroecology is only mentioned by rural extension agents and is supported by local NGOs in Altamira (table 2). Indeed, the isolation of the area has affected both the population's way of thinking and the local dynamics in a way that is favorable for autonomous agricultural models. However, this alternative is not really collectively implemented and is mainly looked on as a desirable agricultural shift for the future of family farms, "a utopian idea" according to a member of the staff of a rural extension service.

\section{How do these}

\section{alternatives relate to ecological intensification?}

Historically, in the Amazon, livestock was a way of securing land ownership, whereas production was less of a priority. In this context, intensifying livestock farming is a difficult step for both large and small family farmers. Our results show that all stakeholders involved in cattle production perceive the need to shift from extensive and forest damaging practices to environmentally friendly practices. But their knowledge mainly concerns intensification sensu stricto, i.e. increasing productivity per plot or per animal. Aside from respecting the law on the preservation of the forest ecosystem, stakeholders appeared to be little concerned by ecological aspects. Alternatives are rarely based on ecosystem functioning. They mainly rely on conventional techniques using chemical inputs, genetics and equipment but seek to reduce the negative impact on the environment. Thus, most alternatives are more in line with "weak ecological intensification" (Duru et al., 2014). They are considered to be "universal", i.e. suitable for both small and large farmers, but they do not account for the specificities of family farms in terms of the knowledge, cash management and investment capacity, and the consequences of their application for the work load. Agro-forestry systems and agro-ecology are more in line with improved integration of production and the ecosystem. Indeed, agro-forestry systems are one of the alternatives specifically mentioned for 
the future of family farms in the Amazon (the other alternative dedicated to family farming is dairy intensification). Both alternatives agroforestry and agro-ecology - are models of land sharing, with the idea of increasing land and labor productivity. Concerning agro-ecology, only a few isolated experiments have been conducted, and these systems are considered to be "utopian" or difficult to implement (table 2). Models like balde cheio lacks context-specific knowledge and they do not account for the range of different farm scales and types of organization. The family work load and market opportunities are the main obstacles to their application in remote areas, especially on family farms (Carvalho, 2011), with the exception of certain key products such as açaí berries (Cialdella and Navegantes, 2014).

Given the decline in deforestation, the political consortium for "zero deforestation" can be said to have achieved its goal following a traditional approach to nature conservation based on a "land sparing" strategy. However, the land sparing strategy appears to be most efficient for conserving biodiversity in fragmented landscapes, where few natural ecosystems survive in landscapes the majority of which is cultivated (Egan \& Mortensen, 2012). Land sparing strategies are thus appropriate in highly deforested regions like Redenção or Paragominas municipalities, which accounts for about $17 \%$ of the Brazilian Amazon. The Low Carbon Program for Agriculture (Brazilian acronym Programa ABC) (MAPA, 2012) and the National Plan for Agroecology and Organic Production (Brazilian acronym PLANA-PO) (MDA, 2013) are emblematic of the choices made by the federal government today. The first is recommended for all types of farms, large or small, once the requirements are met. But with the exception of the balde cheio alternative, family farms often cannot meet these requirements.

Supported by the Ministry of Agriculture (MAPA), the ABC program aims to reduce the carbon impact of the Brazilian food sector; it had a 3.15 billion $\mathrm{R} \$(\mathrm{R} \$ 1=\mathrm{US} \$ 0.328 \mathrm{USD})$ budget in 2011/2012. The Ministry of Rural Development (MDA) is interested in sustainable rural and local development, especially in strengthening small family farmers. The PLANA-PO program, supported by the MDA, aims to improve organic production, agroforestry systems, and land-sharing alternatives. Its budget was about $\mathrm{R} \$$ 260 million in 2011/2012. For many reasons linked to the history of Brazil and to economic issues, the Brazilian government strongly supports these two contrasted sets of policies.

The financial discrepancy between the two programs partly explains the Brazilian government's position on development and conservation policy, and also why local actors know little about these models. We also wonder to what extent the lack of alternatives aimed at "strong ecological intensification", i.e. mimicking nature to encourage natural and free ecological processes, could be due to technological lock-in (Van Loqueren and Baret, 2009). The two policy trends support and also reinforce the idea that family farmers have to be more embedded in nature while cropping than agribusiness. This dichotomy is partly a consequence of land planning and scale of action (state and federation) of the policy, but it erases environmental heterogeneity as far as local land-use and social trades-off (Grau et al., 2013). Real situations are often more complex. The coordination of federal and local actions thus needs to be strengthened to promote a set of good practices to further improve the trend of reducing deforestation (Araújo et al., 2010).

\section{Conclusion}

Amazonian colonization was made possible by the development of extensive cattle ranching, based on destroying the forest. Today, this model of agriculture is challenged by different pressures, all of which converge towards zero deforestation. There is thus an urgent need to change the practices of farmers and of stakeholders of the meat supply chain, and in particular to increase the productivity of their production system. Most of the paths to livestock intensification these stakeholders foresee correspond to standard techniques to increase productivity, which were promoted during the green revolution. However, we witnessed a rediscovery, by research and development, of the value of crop rotation, of the management of soil fertility through the use of fallow and pasture, of diversification, and at a larger scale, a search for increased farm autonomy, as well as increased awareness of the ecological and economic role of traditional systems such as agroforestry. Even in this region where both agricultural development and forest conservation are very sensitive issues, the links between intensification and ecology, between livestock and forest, remain to be constructed and need to account for the specific context and diversity of farms, with different constraints and opportunities to adopt different strategies.

\section{Acknowledgments}

The authors would like to thank all the interviewees in Altamira, Paragominas and Redenção and Daphne Goodfellow for correcting the English. This work was funded by the French Agence Nationale de la Recherche under the project ANR-2010STRA-005 MOUVE (Les interactions Élevage et Territoire dans la mise en mouvement de l'intensification écologique).

\section{References}

Altieri M, 2002. Agro-ecology: the science of natural resource management for poor farmers in marginal environments agriculture. Ecosystems and Environment 93:1-24.

Araújo de Oliveira SR, Costa de Assis F, Aguiar APD, Mann de Toledo P, Vieira ICG, Câmara G, 2010. Desmatamento, trajetórias tecnológicas rurais e metas de contenção de emissões na Amazônia. Ciência e Cultura 62(4):56-9.

Balbino LC, Barcellos De AO, Stone LF, 2011. Marco referencial: integração lavoura-pecuáriafloresta (ILPF). Brasília, DF: Embrapa.

Bonny S, 2011. L'agriculture écologiquement intensive: nature et défis. Cahiers Agricultures 20(6):451-62. doi: 10.1684/agr.2011.0526

Camargo de AC, Noaves NJ, Novo ALN, et al., 2006. Projeto balde cheio: Transferência de tecnologia na produção leiteira. Embrapa: Comunicado Técnico; 73 .

Carvalho S, 2011. Entre opportunisme et persistance. Quelles dynamiques et perspectives d'évolution pour les exploitations laitières familiales de la Transamazonienne? Thèse de doctorat : AgroParis Tech, Paris.

Cialdella N, Navegantes-Alves L, 2014. La ruée vers l'açaí : trajectoires d'un fruit emblématique d'Amazonie. Revue Tiers Monde 220:119-35.

Copans J, 1999. L'enquête ethnologique de terrain : l'enquête et ses méthodes. Paris: Armand Colin. 
Doré T, Makowski D, Malézieux E, Munier-Jolain N, Tchamitchian $M$, Tittonell $P, 2011$. Facing up the paradigm of ecological intensification in agronomy: revisiting methods, concepts and knowledge. European Journal of Agronomy 34:197-210.

Duru M, Fares M, Therond O, 2014. Un cadre conceptuel pour penser dans les territoires. Cahiers Agricultures 23:84-95. doi: 10.1684/agr.2014. 0691

Egan JF, Mortensen DA, 2012. A comparison of land-sharing and land-sparing strategies for plant richness conservation in agricultural landscapes. Ecological Applications 22:459-71.

Grau R, Kuemmerle T, Macchi L, 2013. Beyond 'land sparing versus land sharing': environmenta heterogeneity, globalization and the balance between agricultural production and nature conservation. Current Opinion in Environmental Sustainability 5:477-83.

Griffon M, 2013. Qu'est-ce que I'agriculture écologiquement intensive? Paris: Éditions Quae.

Hubert B, Rosegrant M, van Boekel MAJS, Ortiz R, 2010. The future of food: scenarios for 2050. Crop Science 50:33-50.

IBGE (Instituto Brasileiro de Geografia e Estadisticas), 2010. Produção da Pecuária Municipal. http:// www.ibge.gov.br/home/estatistica/economia/ppm 2010/

Instituto de Pesquisa Ambiental da Amazônia (IPAM), 2011. Desmatamento n'a Amazônia.
http://www.ipam.org.br/saiba-mais/Desmatamentoem-Foco/9

Ministério da Agricultura, Pecuária e Abastecimento, 2012. Plano de agricultura de baixa emissão de carbono - ABC. Brasília: MAPA/ACS.

Ministério do Desenvolvimento Agrário, 2013. Plano Nacional de Agroecologia e produção organica-PLANA-PO. Brasília: MDA.

Nepstad D, McGrath D, Stickler C, et al., 2014. Slowing Amazon deforestation through public policy and interventions in beef and soy supply chains. Science 344:1118-23.

Poccard-Chapuis R, Thales M, Venturieri A, Piketty M-G, Merte S, Veiga JB, Tourrand J-F, 2005. La filière viande : un levier pour contrôler les dynamiques pionnières en Amazonie brésilienne ? Cahiers Agricultures 14(1):53-8.

PRODES, 2010. Monitoramento da Floresta Amazônica Brasilia porc satélite. http://www. obt.inpe.br/prodes/index.php

Santos LDT, Sales NLP, Duarte ER, Oliveira FLR, Mendes LR, eds. Integração Lavoura-PecuáriaFloresta: alternativa para producão sustentável nos trópicos. Montes Claros (Brasil): Instituto de Ciências Agrarias da UFMG.

Sayago D, Tourrand JF, Burstyn M, Drummond JA, 2004. Amazônia. Cenas e cenários. Brasilia: UnB.

Sheil D, Murdiyarso D, 2009. How forests attract rain: an examination of a new hypothesis.
BioScience 59(4):341-7. doi: $10.1525 /$ bio 2009 59.4.12

Soares-Filho B, Moutinho P, Nepstad D, et al., 2010. Role of Brazilian Amazon protected areas in climate change mitigation. PNAS 107(24):108216. doi: 10.1073/pnas.0913048107

Titonell P, 2014. Ecological intensification of agriculture - sustainable by nature. Current Opinion in Environmental Sustainability 8:53-61.

Tourrand JF, Piketty MG, Oliveira JRD, et al., 2002. Élevage bovin, déforestation et développement régional : le cas du Sud du Pará, Amazonie brésilienne. Bois et Forêts des Tropiques 280:5-16.

Vanloqueren G, Baret PV, 2009. How agricultural research systems shape a technological regime that develops genetic engineering but locks out agroecological innovations. Research Policy 38:971-83.

Vaz V, Carvalho S, Barnosa T, et al., 2012. A pecuária na agenda ambiental da Amazônia brasileira: percepções e representações dos atores locais. Dossiê Rede de Estudos Rurais 3:64-90.

Veiga J, Tourrand JF, Piketty M, et al., 2004. Expansão e trajetórias da pecuária na Amazônia. Brasília-DF: UNB.

Wezel A, Bellon S, Doré A, Francis C, Vallod D, David C, 2009. Agroecology as a science, a movement and a practice. A review. Agronomy for Sustainable Development 29(4):503-15. 